\title{
C- Line Polymorphism in Human Populations
}

\author{
Giovanni Floris* \\ University of Cagliari - Natural Sciences, Via Corte d'Appello, 42 - 09124 CAGLIARI, Italy \\ *Corresponding author: Giovanni Floris, University of Cagliari - Natural Sciences, Via Corte d’Appello, 42 - 09124 \\ CAGLIARI, Italy
}

\section{ARTICLE INFO}

Received: 幽 March 09, 2020

Published: 幽 March 13, 2020

Citation: Giovanni Floris. C-Line Polymorphism in Human Populations. Biomed J Sci \& Tech Res 26(4)-2020. BJSTR. MS.ID.004375.

\begin{abstract}
Data on C- line terminations as established by Plato [1] are reported for various populations with reference to the radial terminations/ulnar terminations ratio. The examined populations are heterogeneous and can be divided between those with a Radial type/Ulnar type ratio less than 1 and those with a ratio greater than 1 .
\end{abstract}

Keywords: Dermatoglyphics; C Line; Human Populations

\section{Short Communication}

The study of dermatoglyphic, hereditary characteristics, which take on their final form in about the fourth month of intra-uterine life, is a great help towards a better knowledge of the different human populations Maxia, et al. [2]. Of the different dermatoglyphic characteristics we choose in this work the terminations of the $\mathrm{C}$ line .In 1970, Plato classified the terminations of the C line (the main line departing from $\mathrm{c}$ triradius at the base of the ring finger, Cummins, et al. [3] into four modal types:

a. Ulnar type (terminations 4, 5, 6, 7), toward the little finger and area proximal to it (hypothenar area);

b. Radial type (terminations 9, 10, 11, 12, 13), toward the thumb and thenar area:

c. Proximal type (terminations $\mathrm{X}, \mathrm{x}, 8$ ), the line folds on itself or is aborted;

d. Absence (0), ctriradius not present.

The Proximal type can be combined with Absence Bhattacharya [4] and the Radial type/Ulnar type ratio can be calculated to determine if this ratio is less than 1 (prevalence of ulnar terminations) or greater than 1 (prevalence of radial terminations).

\section{Study Method}

This note reports data on $\mathrm{C}$ line polymorphism in male populations (because more data are available) from the five continents (Asia is divided into West-Central Asia and South
Asia), thus expanding the previously reported database Floris [5]. The data for Sardinians, Corsicans and Swiss (among European populations) were calculated by the author, while the other data were taken from the literature (see References), The literature data were reprocessed so as to have the raw data (and thus not all literature data were available). The data on Russian populations were taken from Heet [6] precisely via elaboration of the data reported in (Table VII). Only those regarding group 2 were omitted because the percentages do not add up. The Russian population is not included in the calculation of the global chi square.

\section{Results}

(Table 1) reports the values of $\mathrm{C}$ line terminations in the examined populations. A contingency table for the data on the totals of the six considered groups was calculated. The highly significant $X^{2}$ value highlights the heterogeneity of the populations. Examination of the Radial type/Ulnar type ratio shows that some populations have a value less than 1 (those of Africa, America, South Asia, Oceania) and others greater than 1 (those of Europe and West-Central Asia).

\section{Conclusion}

The results suggest that dermatoglyphics, once often used to characterize single human populations and then virtually abandoned in favour of other methods such as analysis of DNA and its polymorphisms Floris [7], can still be useful in characterizing populations. In particular, an intriguing fact that seems to emerge 
from the data is the similarity between Africa, America and Oceania through South Asia and the separation of Europe and West-Central Asia. However, it would be important to fill in some gaps, such as the absence of data (at least analyzable and/or easily understood data) of this type for China and the few data for America, in order to achieve a more complete and clarifying result (without considering the many colleagues who have not answered to my request of data): At this point, for an eventual further confirmation of what has been said, I reported in (Table 2) the the data obtained by the Table 1: C-line terminations (\%). angular transformation in radians of the percentage frequencies of the terminations of the C-line (for methodology and bibliography, Cosseddu, et al. [8]. The result is not very different from the dermatoglyphic considerations made earlier [9-40]. I can conclude by hoping that the study of dermatoglyphics (digital, palmar and plantar) does not fall into the oblivion to which it almost seems destined today, but that it may continue to have scientific validity [41-91]

\begin{tabular}{|c|c|c|c|c|c|c|}
\hline \multicolumn{7}{|c|}{ Africa } \\
\hline Population & Sample size & Groups & Ulnar & Radial & Proximal +Absence & $R / U$ \\
\hline Malians & 494 & 2 & 45.34 & 36.74 & 17.91 & 0.81 \\
\hline Moroccans & 189 & 1 & 48.41 & 37.30 & 14.29 & 0.77 \\
\hline Nigerians & 398 & 1 & 41.42 & - & 58.50 & - \\
\hline Tunisians & 1852 & 1 & 45.11 & 36.52 & 18.37 & 0.81 \\
\hline Total & 2933 & 5 & 44.86 & 31.65 & 23.49 & 0.71 \\
\hline \multicolumn{7}{|c|}{ America } \\
\hline Population & Sample size & Groups & Ulnar & Radial & Proximal+ Absence & $\mathbf{R} / \mathbf{U}$ \\
\hline Argentines & 143 & 4 & 52.10 & 22.03 & 25.87 & 0.42 \\
\hline Eskimos & 73 & 1 & 50.68 & 30.14 & 19.18 & 0.62 \\
\hline Seminoles & 61 & 1 & 47.54 & 27.05 & 25.41 & 0.57 \\
\hline Venezuelans & 125 & 2 & 64.80 & 11.20 & 24.00 & 0.17 \\
\hline Total & 402 & 8 & 55.10 & 20.90 & 24.00 & 0.38 \\
\hline \multicolumn{7}{|c|}{ South Asia } \\
\hline Population & Sample size & Groups & Ulnar & Radial & Proximal +Absence & $R / U$ \\
\hline Indians & 2368 & 15 & 46.77 & 39.63 & 13.60 & 0.85 \\
\hline Nepaleses & 104 & 1 & 65.35 & 17.31 & 17.31 & 0.26 \\
\hline Total & 2472 & 16 & 47.55 & 38.69 & 13.76 & $0.81 \backslash$ \\
\hline \multicolumn{7}{|c|}{ West-Central Asia } \\
\hline Population & Sample size & Groups & Ulnar & Radial & Proximal +Absence & $R / U$ \\
\hline Iraqis & 71 & 1 & 35.21 & 39.44 & 25.35 & 1.12 \\
\hline Iranians & 2200 & 3 & 35.22 & 46.30 & 18.48 & 1.31 \\
\hline Israelis & 1010 & 1 & 29.50 & 57.63 & 12.87 & 1.95 \\
\hline Yemenis & 106 & 1 & 39.69 & 33.00 & 27.40 & 0.83 \\
\hline Lebaneses & 240 & 1 & 39.20 & 41.00 & 19.70 & 1.05 \\
\hline Turks & 200 & 1 & 31.50 & 55.50 & 13.00 & 1.76 \\
\hline Total & 3827 & 8 & 33.89 & 48.94 & 17.17 & 1.44 \\
\hline \multicolumn{7}{|c|}{ Europe } \\
\hline Population & Sample size & Groups & Ulnar & Radial & Proximal +Absence & $\mathrm{R} / \mathrm{U}$ \\
\hline Albanians & 517 & 2 & 40.23 & 46.62 & 13.15 & 1.16 \\
\hline Austrians & 150 & 1 & 34.33 & 49.67 & 16.00 & 1.45 \\
\hline Basques & 102 & 1 & 39.59 & 47.72 & 12.69 & 1.21 \\
\hline Bulgarians & 1574 & 3 & 38.37 & 45.55 & 16.08 & 1.19 \\
\hline Corsicans & 50 & 1 & 45.00 & 33.00 & 22.00 & 0.73 \\
\hline French & 335 & 1 & 37.01 & 43.58 & 19.41 & 1.15 \\
\hline Greeks & 289 & 2 & 34.40 & 46.30 & 19.29 & 1.35 \\
\hline $\begin{array}{l}\text { Italians (without } \\
\text { Sardinians) }\end{array}$ & 670 & 6 & 41.79 & 39.48 & 18.73 & 0.94 \\
\hline
\end{tabular}




\begin{tabular}{|c|c|c|c|c|c|c|}
\hline Poles & 2138 & 2 & 36.53 & 39.33 & 24.14 & 1.08 \\
\hline Sardinians & 1000 & 1 & 41.70 & 36.85 & 21.45 & 0.88 \\
\hline Spaniards & 1216 & 6 & 43.97 & 41.79 & 14.23 & 0.95 \\
\hline Swiss & 28 & 1 & 42.86 & 33.93 & 23.21 & 0.79 \\
\hline Germans & 1281 & 1 & 40.83 & 45.86 & 13.31 & 1.12 \\
\hline $\begin{array}{c}\text { Russians } \\
\text { Hungarians }\end{array}$ & $\begin{array}{c}5382 \\
642\end{array}$ & $\begin{array}{l}1 \\
1\end{array}$ & $\begin{array}{l}41.58 \\
38.40\end{array}$ & $\begin{array}{l}39.92 \\
39.00\end{array}$ & $\begin{array}{l}18.50 \\
23.00\end{array}$ & 0.91 .02 \\
\hline Total & 15374 & 30 & 40.20 & 41.34 & 18.46 & 1.03 \\
\hline \multicolumn{7}{|c|}{ Oceania } \\
\hline Population & Sample size & Groups & Ulnar & Radial & Proximal +Absence & $\mathrm{R} / \mathrm{U}$ \\
\hline Micronesians & 1836 & 2 & 63.78 & 16.61 & 19.61 & 0.26 \\
\hline New Guineans & 498 & 1 & 57.23 & 22.49 & 20.28 & 0.39 \\
\hline Polynesians & 117 & 1 & 58.97 & 29.92 & 11.11 & 0.51 \\
\hline Total & 2451 & 4 & 62.22 & 18.44 & 19.34 & 0.30 \\
\hline
\end{tabular}

Note: $X^{2}=891.47$ d.f. $=10$ p $<0.001$

Table 2: Angular transformation in radians of the percentage frequencies.

\begin{tabular}{|c|c|c|c|c|c|}
\hline & Europe & South Asia & West-Central Asia & America & Oceania \\
\hline Africa & 17.77 & 24.06 & 55.14 & 27.82 & 61.96 \\
\hline Europe & - & 11.38 & 11.20 & 84.00 & 124.92 \\
\hline South Asia & - & - & 35.14 & 156.64 & 210.96 \\
\hline West-Central Asia & - & - & - & 67.52 & 86.99 \\
\hline America & - & - & - & - & 10.33 \\
\hline
\end{tabular}

\section{References}

1. Plato CC (1970) Polymorphism of the C Line of Palmar Dermatoglyphics with a New Classification of the C Line Terminations. American Journal of Physical Anthropology 33(3): 413-420.

2. Maxia C, Floris G (1974) Dermatoglyphic in Endogamic Populations of Sardinia. Journal of Evolution 3(1): 51-64.

3. Cummins H, Midlo C (1961) Fingerprints palms and soles Dover New York, USA.

4. Bhattacharya DK (1971) Variation of C-line terminations in palmar dermatoglyphics: three coordinate as possible method of population discrimination. The Anthropologist 18: 41-44.

5. Floris G (2014) Polymorphisms della linea C nei Sardi. Variabilità umana tra passato e presente a cura di In: C Peretto, M Arzarello, J Arnaud (Eds.)., 10/2, Università degli Studi di Ferrara, pp. 275-278.

6. Heet H (1983) Studio dei Dermatoglifi nell'USSR. Mosca (translated by Russian).

7. Floris G (2006) I Dermatoglifi. Il processo di umanizzazione a cura di In: A Guerci, S Consigliere, S Castagno (Eds.)., Atti XVI Congresso degli Antropologi Italiani Edicolors Publishing Milano p. 1-2.

8. Cosseddu GG, Floris G, Vona G (1979) Sex and Side Differences in the Minor Non-metrical Cranial Variants. Journal of Human Evolution 8(7): 685-692.

9. Abdullah NF (1982) Genetical Variation in Palmar Features. In: CS Bartsocas (Eds.)., Progress in Dermatoglyphic Research, AR Liss Inc, New York, USA. pp. 269-284.

10. Alciati G, Andreatta G, D’Agostini G, Parnigotto PP (1978) I dermatoglifi nei Colli Euganei: confronto con altre zone d'Italia. Antropologia Contemporanea 1: 161-173.

11. Andreenko E, Baltova S (2017) Sexual dimorphism in dermatoglyphic traits and fluctuating asymmetry in Bulgarians from southwest Bulgaria. Homo 68(4): 316-327.
12. Atasu M (1993) Digital and Palmar Dermatoglyphics of Turkish Children. Newsletter of the ADA 12 (1): 3-8.

13. Balgir RS (1984) Polymorphism of palmar C- and D-line terminations among the Sikligars of Chandigarth. American Journal of Physical Anthropology 65(2): 199-200.

14. Bansal IS, Bhattacharya DK (1972) Inheritance of C-line termination types in palmar dermatoglyphics. Zeitschrift fur Morphologie und Anthropologie 63(3): 385-390.

15. Baruah P (1999) A short note on the palmar C line polymorphism among the Ahom of Dibrugarh district. The Anthropologist Assam 1(4): 285286.

16. Bartsocas CS, Panayotou TH, Varonos S, Kritsikis S, Plato CC, et al. (1982) Digital and Palmar Dermatoglyphics in Greeks. In: CS Bartsocas (Edt.)., Progress in Dermatoglyphic Research. AR Liss, Inc. New York, USA. 84: 247-267.

17. Butt NA (1991) A palmar dermatoglyphic study among the Ahmadiyya muslim males of Qadian, Punjab. In: BM Reddy, S Roy, BN Sarkar (Eds.)., Dermatoglyphics Today, Calcutta, IBRAD, pp. 399-403.

18. Benes J (1965) Palmardermatoglyphik der Slowakischen Zigenner (Tschechoslowakei). AnthropologieIII 1: 27-35.

19. Chamla MC, Salhy A (1972) Les empreintes digitales et palmaires des Tunisiens. Libyca XX p. 11-31.

20. De Diaz Ungria AG (1978) Dermatoglyphics in two Yukpa groups from the Sierra de Perija: Chaparro and Pariri. In: J Mavalwala (Eds.)., Dermatoglyphics-An International Perspective, The Hague-Paris, Mouton Publishers, pp. 107-129.

21. D'Amore C, Galgano M (1963) I dermatoglifi palmari in 100 maschi e 100 femmine napoletani. Rendiconti Accademia Scienze Fisiche e Matematiche di Napoli 63(4): 315-343.

22. D’Amore C, Galgano M (1966) I dermatoglifi palmari in un gruppo di abitanti di Roccarainola (Napoli): confronto dei dati con quelli noti 
per altri gruppi del ramo degli Europoidi. Rendiconti dell'Accademia di Scienze Fisiche e Matematiche della Società Nazionale di Scienze Lettere ed Arti in Napoli 33: 242-256.

23. Deep Kumar VS, Ramachandraiah T (1991) Finger and palmar dermatoglyphic study among the Narikoravam. In: B:M: Reddy, SB Roy, BN Sarkar (Eds.)., Dermatoglyphics Today, Calcutta, IBRAD, pp. 343-355

24. Demarchi DA, Marcellino AJ (1994) Dermatoglyphics among the Mataco Indians of the Gran Chaco (Argentina). Dermatoglyphics 13(4): 29-34.

25. Demarchi DA, Marcellino AJ (1995) Dermatoglyphics in Pilaga Indians of the Gran Chaco (Argentina). Dermatoglyphics 14(4): 11-27.

26. Deva SRS, Prakash Godi, Sudhakar (2010) Palmar C-line variation among Yerukula. a nomadic tribe of South India Antrocom 6(1): 21-24.

27. Dorjee B, Das S, Mondal N, Sen J (2015) Dermatoglyphic variation among the Limboo of Sikkim, India. Homo 66 (5): 455-470.

28. Esteban E, Moral P (1992) Dermatoglifos cualitativos palmares en la poblaciòn de Murcia. Boletin de la Sociedad Espanola de Antropologia Biologica 13: 89-102.

29. Floris G, Marini E, Petralanda I (1994) Digital and Palmar Dermatoglyphics in the Piaroa Indians (Amazonia Federal Territory, Venezuela). Dermatoglyphics 13(4): 9-28.

30. Floris G, Sanna E (1987) I dermatoglifi qualitative palmary come indicatori di relazioni tra le popolazioni maschili della Sardegna. Rivista di Antropologia 65: 233-248.

31. Formicola V (1976) I dermatoglifi digitali e palmari di 200 lunigianes (100 maschi e 100 femmine). Atti della Società Toscana di Scienze Naturali 82: 97-111.

32. Formicola V, Lucchesi L (1982) Nuovi dati sui dermatoglifi digitali e palmari in campioni apuani. Antropologia Contemporanea 5(3-4): 255267.

33. Fox KM, Garruto RM, Gajdusek DC, Plato CC (1990) Dermatoglyphics of the Isolated Kapingamaramgese of Micronesia. Trends in Dermatoglyphic Research. In: NM Durham, CC Plato (Eds.)., Kluwer Academic Publishers, pp. 278-286.

34. Fox KM, Plato CC, Garruto RM, Gajdusek DC (1987) A Review of the Dermatoglyphics of Micronesia. Collegium Antropologicum 2: 355-372.

35. Francis J (1991) A comparative study of palmar C-line polymorphism among the two communities of Kerali. In: BM Reddy, SB Roy, BN Sarkar (Eds.)., Dermatoglyphics Today, Calcutta, IBRAD, pp. 367-372.

36. Garg RK (1985) C-line polymorphism of the palmar dermatoglyphics among the Gaur Brahmins. Canadian Review of Physical Anthropology India 4(2): 53-55.

37. Ghalib MA, Lantigua A (1991) Dermatoglyphic studies of normal adult yemenis of both sexes. In: BM Reddy, SB Roy, BN Sarkar (Eds.)., Dermatoglyphics Today, Calcutta, IBRAD, pp. 270-275

38. Ghatage VA, Thambidorai CVK, Bhanu BV (1977-1978) A study of the Association between finger patterns and C-line terminations. Bulletin of Decan College Research Institute 37(1-4): 34-38.

39. Gladkova TD, Toth TA (1978) Hungarian Dermatoglyics and their relation to the origin of the Hungarian people. In: J Mavalwala (Eds.). Dermatoglyphics-An International Perspective, The Hague-Paris, Mouton Publishers (only males), pp. 167-176.

40. Glanville EV, Huizinga J (1966) Palmar dermatoglyphics of the Dogon and Peul of Mali. proceedings Koninkl Nederl Akademie Van Wetenschappen sC 69(4): 528-539.

41. Gualdi Russo E (1987) Palmar dermatoglyphics in a sample of Italian population. International Journal of Anthropology 2(2): 105-116.

42. Haque M, Alam S (1991) Finger and palmar dermatoglyphics of the Sunny muslims of Hooghly. West Bengala In: BM Reddy, SB Roy, BN Sarkar (Eds)., Dermatoglyphics Today, Calcutta, IBRAD, pp. 404-409.
43. Harpending HC, Jenkins T (1973) Genetic distance among southern African populations. In: Grawford MH, Workman PL (Eds.)., Methods and theories in anthropological genetics, Albuquerque, University of New Mexico Press, pp. 177-199.

44. Hauser G, Abraham R (1985) Size and Shape in dermatoglyphic analysis of palmar interdigital areas. Annals of Human Biology 12(1): 53-66.

45. Hoff C, Plato CC, Garruto RM, Dutt J (1981) Dermatoglyphic Assessment of Genetic Relationships of Native American Populations. American Journal of Physical Anthropology 55: 455-461.

46. Jajd BNR, Igbigbi PS (2010) Termination patterns of the palmar C-line in Nigerian populations: a comparative study of two groups. Australian Journal of Basic and Applied Sciences 4(9): 4435-4439.

47. Jami J, Limbu DK (2015) Digital and Palmar Dermatoglyphics of the Bhoi Khasis of Umden Village. Ri-Bhoi District, Meghalaya, Journal of Life Science 7(1-2): 12-14.

48. Kamali MS (1982) Dermatoglyphics of Iranians of African descet. Dermatoglyphics 10(2): 4-15.

49. Kamali MS (2009) Distance Analysis of C- and D-lines Terminations in Iranian Populations. Anthropologischer Anzeiger 67(3): 281-293.

50. Kamali MS, Mavalwala J, Bhanu BV (1990) Diversity of C-line Terminations in Iranian Populations. American Journal of Physical Anthropology 81: 527-533.

51. Katayama K (1990) Dermatoglyphics of Native Polynesians in the Cook Islands, and their biological positioning among south Pacific populations. Trends in Dermatoglyphic Research. In: NM Durham, CC Plato (Eds.)., Kluwer Academic Publishers, pp. 258-278.

52. Keita B (1983) New Data on Digital and Palmar Dermatoglyphic of the Bozo and Somono Populations from Kirango. Mali, Collegium Antropologicum 7: 149-164.

53. Larrick JW, Plato CC (1983) Digital and Palmar Dermatoglyphic Patterns among Natives of Extreme Northwest Nepal. Human Heredity 33(5): 322-325.

54. Liczbinska G (1998) Palm dermatoglyphics of the Cashubians from the Hel peninsula.Newsletter of the American Dermatoglyphics Association 17: 2-9.

55. Luna F, Pons J (1987) The dermatoglyphics of the Eastern Andalusia. International Journal of Anthropology 2(2): 183-190.

56. Malhotra R, Sarkar BN (1984) Quantitative digital and palmar dermatoglyphics of the Nicobares. Dermatoglyphics 12 (1,2): 59-67 (only males).

57. Martin MJ (1991) Palmar C-line polymorphism in Spain. In: BM Reddy, SB Roy, BN Sarkar (Eds.)., Dermatoglyphics Today, Calcutta, IBRAD pp. 245-255.

58. Naffah J (1974) Dermatoglyphics and Flexion Creases in the Lebanese Population. American Journal of Physical Anthropology 41(3): 391-410.

59. Narahari S, Malati KSK, Dev KRSS (2008) The Khond: A Dermatoglyphic Study. The Anthropologist 10(3): 207-210.

60. Ocampo SB, Dipierri JE, Marcellino AJ (1988) Les dermatoglyphes des Matacos: analyse qualitative et quantitative. Bulletins et Mémoires de la Société d'Anthropologie de Paris 5(3): 199-212.

61. Oyhenart Perera MF (1983) Dermatoglifos en Gallegos. Caracteres de apreciacion qualitative Acta III Congresso de Antropologia Biologica de Espana Santiago de Compostela pp. 386-399.

62. Parvatheesam C, Babu BV (1997) Palmar C-line polymorphism among Rajaka of Andhra Pradesh. Journal of Human Ecology 8(2): 149-150.

63. Pereira M, Petit Marie N, Jagolnitzer ER (1977) Dermatoglyphes digitaux et palmaires d'Israeliens. Bulletins et mémoires de la Société d'Anthropologie de Paris 4 XIII s (3): 245-263. 
64. Plato CC, Brown HA, Gajdusek DC (1975) The Dermatoglyphics of the Elema People from the Gulf district of Papua New Guinea. American Journal of Physical Anthropology 42(2): 241-250.

65. Plato CC, Cereghino J, Steinberg FS (1975) The Dermatoglyphics of American Caucasians. American Journal of Physical Anthropology 42(2): 195-210.

66. Plato CC, Gajdusek DC (1972) Genetic Studies in Relation to Kuru IV. Dermatoglyphics of the Fore and Anga Populations of the Eastern Highlands of New Guinea. American Journal of Human Genetics 24 suppl p. 86-94.

67. Plato CC, Gajdusek DC, Mac Lennan R (1978) The dermetoglyphics of the Peoples of New Guinea: A review. In: J Mavalwala (Eds.). Dermatoglyphics-An International Perspectice, The Hague-Paris, Mouton Publishers, pp. 195-214.

68. Plato CC, Mac Lennan R (1975) The dermatoglyphics of the Maprik sub district of the Sepic district of New Guinea. Zeitschrift fur Morphologie und Anthropologie 66(2): 208-216.

69. Pons J (1952) Impresiones dertmopapilares en estudiantes universitarios barceloneses. Trabajos del Instituto Bernardino de Sahagùn de Antropologia y Etnologia 13(2): 87-131.

70. Pons J (1953) Impresiones dermopapilares en varias poblaciones (Bantù de Natal, Bereberes de Giado, Garaitas de Polonia y Dauada del Fezzan). Trabajos del Instituto B. de Sahagùn de Antropologia y Etnologia 14(1): 7-26.

71. Pons J (1954) Impresiones dermopapilares en vascos y su relaciòn con otras poblaciónes. Trabajos del Instituto B. de Sahagùn de Antropologia y Etnologia 14(3): 58-78.

72. Prakash SRS, Sudhakar G (2010) Palmar C-line Variation among Yerukula a Nomadic Tribe of South India. Antrocom 6(1): 21-24.

73. Qazi QH, Mapa HC, Woods J (1977) Dermatoglyphics of American Blacks. American Journal of Physical Anthropology 47(3): 483-488.

74. Reddy KS, Reddy KN (1999) Palmar C-line polymorphisms in four subcastes of Reddis of Andhra Pradesh. The Anthropologist 1(2): 151-153.

75. Reddy BKC, Reddy KSN, (2006) A study of palmar dermatoglyphics among Sugalis, a tribal population of Andhra Pradesh. The Anthropologist 8(1): 21-24.

76. Rife DC (1968) Finger and palmar dermatoglyphics in Seminole Indians of Florida. American Journal of Physical Anthropology 28(2): 119-126.

77. Rogucka E (1973) Variation and inheritance of dermatoglyphic features of the palma. Materialow I Prac Anthropologicznych 86: 55-86.
78. Sanna E (1984) Palmar C-line polymorphism among the Sardinian people. Dermatoglyphics 12(2): 97-98,

79. Sanna E, Floris G (1995) Polymorphism of Palmar Main Line Terminations as Indicator of Relationships among Sardinian Linguistic Groups of Males. Human Biology 67(2): 265-282.

80. Satyanarayana Rao KV (1984) The Dermatoglyphics of the Konda Reddys. Dermatoglyphics 12(1-2): 49-58.

81. Sharma PD, Sahu B (1973) Finger, Palmar, Middle and Basal Phalangeal Dermatoglyphic Study of the Oraons of Rauchi, India. Journal Anthrop Soc Nippon 81(4): 260-267.

82. Siungh SP, Garg RK (1985) Palmar dermatoglyphics of the Spitians of the north-west Himalayas. Dermatoglyphics 13(1,2): 10-14.

83. Steinberg FS, Cereghino JJ, Plato CC (1975) The Dermatoglyphics of American Negroes. American Journal of Physical Anthropology 42(2): 183-194.

84. Sturrock K, Rocha J (2000) A multidimensional scaling stress evaluation table. Field Methods 12: 49-60.

85. Tarca A (1995) The polymorphism of the Cline of palmar dermatoglyphics and its use in population and human pathology studies. Rev Med Chir Soc Med Nat Iasi 99(3-4): 281-290.

86. Temaj G, Krajacic P, Milicic J, Skaric Juric T, Behluli I, et al. (2011) Comparative Analysis of Qualitative Dermatoglyphic Traits of Albanian and Turkish Populations Living in the Area of Dukagin Valley in Kosovo. Collegium Antropologicum 35(3): 905-910.

87. Temaj G, Petranovic MZ, Skaric Juric T, Behluli I, Narancic NS, et al. (2012) A detection of micoroevolutionary changes by the analysis of qualitative dermatoglyphic traits: an example of Albanians from Kosovo. Anthropologischer Anzeiger 69(4): 461-472.

88. Tornjova Randelova S, Paskova Topalova D, Yordanov Y (2011) Dermatoglyphics in Anthropology and Medicine. Academic Publishing House Sofia.

89. Tyagi D, Kiran Maseidan (1974) C-Line Termination Polymorphism in Palmar Dermatoglyphics. Indian Anthropologist 4(2): 131-136.

90. Vrydagh Laoureux S (1979) digital and palmar dermatoglyphics in a sample of Moroccans. Human Biology 51(4): 537-549.

91. Vrydagh S, Auger Fr, Leguebe A (1987) Dermatoglyphes des Eskimo de Fort-Chimo (Canada). Bulletin et Mémoires de la Société Royale Belge d'Anthropologie et de Prèhistoire 98: 235-273.
ISSN: 2574-1241

DOI: $10.26717 /$ BJSTR.2020.26.004375

Giovanni Floris. Biomed J Sci \& Tech Res

This work is licensed under Creative

Commons Attribution 4.0 License

Submission Link: https://biomedres.us/submit-manuscript.php

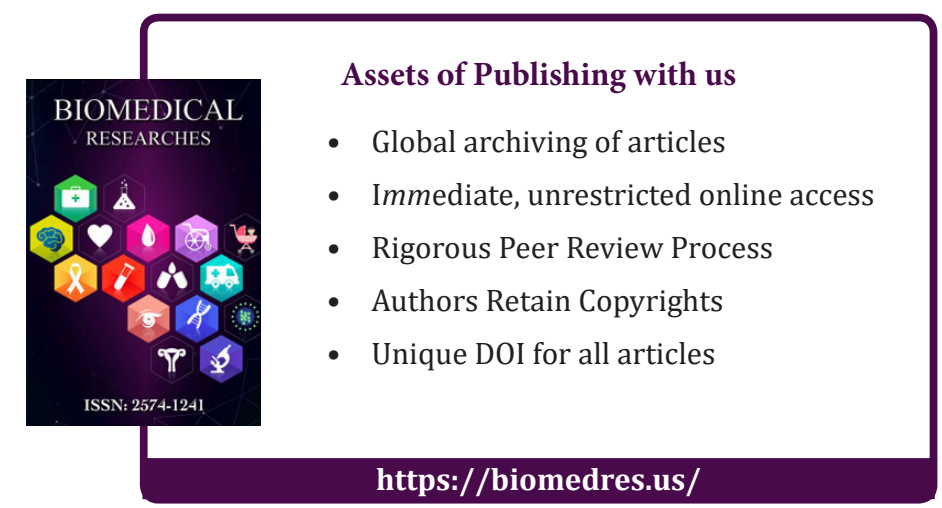

